\title{
EFFECT OF POTASSIUM FERTILIZER TREATMENT ON GROWTH PARAMETERS OF SOME ARCHAEOPHYTE TAXA
}

\author{
Károly Ecseri ${ }^{1}$, Péter Honfi ${ }^{2}$ \\ ${ }^{1}$ John von Neumann University, Faculty of Horticulture and Rural Development, Kecskemét, \\ Hungary \\ ${ }^{2}$ Szent István University, Faculty of Horticultural Science, Budapest, Hungary \\ ecseri.karoly@kvk.uni-neumann.hu
}

\begin{abstract}
The aim of our study was to evaluate the effect of fertilization on segetal vegetation, and determine the level of potassium sensitivity in case of three wildflower species.

The investigated model species were: Cyanus segetum Hill. (cornflower), Consolida orientalis GRAY. (larkspur) and Papaver rhoeas L. (poppy). The fertilizer (potassium chloride $60 \%$ ) was applied on the $14^{\text {th }}$ of October 2016 (at the same time with sowing). Each plot received $9.375 \mathrm{~g}, 18.75 \mathrm{~g}, 37.5 \mathrm{~g}$ and $75 \mathrm{~g}$, which is equivalent of $25,50,100,200 \mathrm{~kg} /$ ha potassium active ingredient. One plot was $1.5 \times 1.5 \mathrm{~m}$. During the trial we did not applied any form of agro- or phytotechnical method, the plants were extensively maintained. The examination method based on horizontal and vertical plant parameters, on phenological stages comparison.

The spring development (growth of rosette) began at $800^{\circ} \mathrm{C}$ in the case of Cyanus segetum and Papaver rhoeas, while the overwintered seedlings of Consolida orientalis developed after a heat sum of $900-1100^{\circ} \mathrm{C}$. Due to autumn sowing, the vegetation period started in 2017 10-14 days earlier than in the 2016 experiment, when the sowing date was in February.

Nutrient application increased the height of plant, but did not affect the width and length of the plants. The positive effect were detectable in all treatments (Papaver rhoeas); or just $100 \mathrm{~kg} / \mathrm{ha}$ treatment (Cyanus segetum and Consolida orientalis). Treatment accelerated the growth of Consolida orientalis plants. Positive effect of treatment was observed in terms of germination percentages and overwintering of poppy plants.
\end{abstract}

Keywords: cornflower, larkspur, poppy, vegetative development, heat sum

\section{INTRODUCTION}

Large amount of potassium is present on the surface of clay minerals, but is only slightly accessible (HORINKA, 2010). Natural potassium replacement (buffering ability of soil) occurs through ion exchange on the surface of clay minerals and depends on the amount and composition of clay minerals. Soils with low clay content and sandy texture have a higher soil solution concentration, lower potassium content and weaker buffer capacity (LOCH ET AL. 2006). It plays an important role in the development of fruit quality parameters (HORINKA, 2010). Moreover, it also enhances frost tolerance, because of lower freezing point in the cellular fluid, for example in the case of overgrown herbaceous plants. It also has a proven effect on pathogen resistance, as it enhances stalk strength through the reinforcement of cell walls and reduces damage to aphid species (PETHÖ, 2002; HARGITAI, 2005; LOCH ET AL. 2006).

Deficiency of potassium causes yellowing from the top of the leaves. The small, necrotizing patches appear only in the tissues between the leaf veins (HARGITAI, 2005). Overdose - due to ion antagonism - results generally relative deficiency of other cations (Hodoss et al. 2004). Deficiency of potassium reduces the abiotic stress tolerance: it increases sensitivity to high light intensity (easy to form chlorotic and necrotic patches on the leaf) and cold; drought and salt stress sensitivity (CAKMAK, 2005). Potassium treatment 
under drought stress increased photosynthetic activity and the amount of carbon stored in the roots in case of some legume species (SNAGAKKARA et al. 2000).

\section{MATERIAL AND METHOD}

The experiment was carried out in 2016-17 at the Presentation Garden of the Faculty of Horticulture and Rural Development of John von Neumann University ( $46^{\circ} 55^{\prime} 10^{\prime} \mathrm{N}, 19^{\circ}$ 41 ' $13^{\prime}$ E). The soil is sand based, constantly cultivated, weed free. The marking of plots and plowing to $20 \mathrm{~cm}$ deep was on 19 September 2016. Even, aerated, small particle size sowing bed was made after plowing. Then, on October 14, 2016, we planted 15 plots. Cornflower and larkspur seeds were incorporated 1-2 cm deep, poppy seeds were scattered on the surface. Sowing was not irrigated due to adequate soil moisture, the weather forecast predicted ample precipitation. During the trial we did not applied any form of agro- or phytotechnical method, the plants were extensively maintained.

Seeds quantities sown:

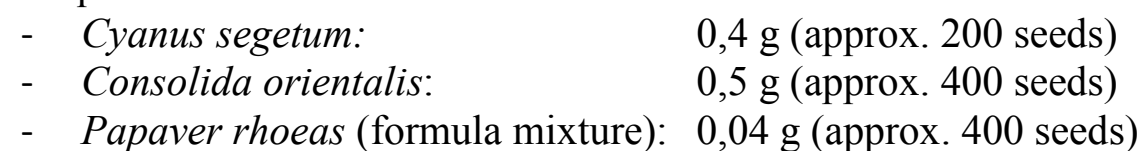

Plant species in the same treatment were put in one plot, there was a $20 \mathrm{~cm}$ walkway between treatments. The marking of plots were made with a $50 \mathrm{~m}$ tape measure, the edges were marked with $50 \mathrm{~cm}$ wooden sticks. One plot was $1,5 \times 1,5 \mathrm{~m}$. The fertilizer (potassium chloride $60 \%$ ) was applied on the $14^{\text {th }}$ of October 2016 (at the same time with sowing) on the 12 plots. Each plot received 9,375 g, 18,75 g, 37,5 g and $75 \mathrm{~g}$, which is equivalent of $25,50,100,200 \mathrm{~kg} /$ ha potassium active ingredient.

Examination method based on phenological observations (measurement of horizontal dimensions of seedlings before flowering - May 15, 2017, and height measurement in the middle of flowering - 22-23 June 2017).

The statistical assessments were made by using singlefactorial analyses of variance (ANOVA) and multifactor correlation tests. Significant difference was determined by Tukey's test $(\alpha=0,05)$. For assaying, we used SPSS 20 program (IBM, New York, US).

\section{RESULTS}

\section{Cyanus segetum}

The germination of seeds was nearly $100 \%$ based on plant number determination. Just in case of $200 \mathrm{~kg} / \mathrm{ha}$ treatment was significantly less (149 plants developed about 200 seeds). Rapid spring development was observed on the plots when vegetative stages were compared. Most of the plants were still in 2-3 leaf stage on March 24, but the shoots started to grow on March 31, and 9 well-developed leaves were formed on April 6th. Then followed a continuous shoot elongation on 2nd-3th decade of April. At least 9 wellseparated internodes were formed at the beginning of May, on each plot and the first flower buds appeared. Side shoots also developed until first decade of May (3-7 pieces per plant). The beginning of flowering was on May 15 th in every plot. The top of flowering was in the last days of May and in the first decade of June. At the same time, the development of achenes was started in the capitulum. The ripening and colouring of the fruits was observed from mid-June. The number of capitulum has decreased since then, 
and the withering of stocks was detected since the last days of June. The end of flowering was on July 25 th, when the dying plots were eliminated.

In the statistical analysis there was no detectable difference in the width and length of the plants ( $\mathrm{SL}<\alpha$, in both cases). When comparing highness data, the Tukey test showed significant difference between the control and the 100 and $200 \mathrm{~kg} /$ ha fertilizer dose plots where the plant height was the highest. There was no significant difference between the plots in the duration of flowering, although the top of flowering in the control area started 5 days before the treated parcels and ended sooner, but there was no difference at the beginning and end of flowering.

\section{Consolida orientalis}

The percentage of germination was lower than Cyanus segetum. Only 117-157 plants developed from the approx. 400 seed at the end of the experiment. Two leaved larkspur seedlings were overwintered and started to develop in March. Nine leaves stages was reached at the first decade of April (50,100 and $200 \mathrm{~kg} /$ ha treatments) and at the end of April $(25 \mathrm{~kg} / \mathrm{ha}$ potassium and control plots). The shoot elongation began similar to cornflower: the first well separable internodes were found one week later in the control and $25 \mathrm{~kg} / \mathrm{ha}$ potassium treated plots. At least 9 internodes were formed until the beginning of May, in every 5 plots and the first buds appeared. Side shoot also developed until middle of May, numbering 1-5 per plant. Analizing this side shoots, significant difference was found. The plants of control and $25 \mathrm{~kg} /$ ha treated parcels were less branching, than plants in $50 \mathrm{~kg} /$ ha parcel (Table 1). This difference can also detect in the length and intensity of flowering.

Table 1. Pairwise comparison of Consolida orientalis side shoots depending on potassium fertilizer application

\begin{tabular}{|l|l|c|c|}
\hline & \multirow{2}{*}{ Treatment } & \multicolumn{2}{|c|}{ Subset } \\
\cline { 3 - 4 } & & 1 & 2 \\
\hline & $25 \mathrm{~kg} / \mathrm{ha}$ & 22.79 & \\
& Control & 22.93 & \\
Tukey & $200 \mathrm{~kg} / \mathrm{ha}$ & 23.00 & 23.00 \\
HSD $^{\text {a,b }}$ & $100 \mathrm{~kg} / \mathrm{ha}$ & 23.14 & 23.14 \\
& $50 \mathrm{~kg} / \mathrm{ha}$ & & 24.00 \\
& Sig. & 0.878 & 0.074 \\
\hline
\end{tabular}

The flowering began in the second decade of May; the top of decoration period was on May 24-26. This time began the development of follicles. The blooming time was finished in the second decade of June, and the ripening and colouring of the fruit happened in the second half of June. Then the stocks die rapidly and completely withered on 30 June. Variance analysis did not show significant differences between treatments (SL $<\alpha$ for both parameters), for the analysis of width and length data. The pairwise comparison of the highness data, it can be concluded that plants on the plots treated with 50 and $100 \mathrm{~kg} / \mathrm{ha}$ are higher than the control plot. The smallest and highest dose treatments caused not higher 
plants than the control (Table 2). There was no significant difference in the generative development, although the end of flowering was on the control plot 3-6 days earlier.

Table 2. Pairwise comparison of Consolida orientalis highness depending on potassium fertilizer application

\begin{tabular}{|l|l|r|r|r|}
\hline & \multirow{2}{*}{ Treatment } & \multicolumn{3}{|c|}{ Subset } \\
\cline { 3 - 5 } & & \multicolumn{1}{|c|}{1} & \multicolumn{1}{c|}{2} & \multicolumn{1}{c|}{3} \\
\hline & Control & 89.55 & & \\
& $200 \mathrm{~kg} / \mathrm{ha}$ & 94.90 & 94.90 & \\
Tukey & $25 \mathrm{~kg} / \mathrm{ha}$ & 100.90 & 100.90 & \\
HSD $^{\text {a,b,c }}$ & $100 \mathrm{~kg} / \mathrm{ha}$ & & 118.35 & 118.35 \\
& $50 \mathrm{~kg} / \mathrm{ha}$ & & & 143.65 \\
& Sig. & 0.762 & 0.113 & 0.072 \\
\hline
\end{tabular}

\section{Papaver rhoeas}

There were significant differences in the number of germinated seedlings. Only $20 \%$ ( 72 plants) of the sown seed (about 400 pieces) were found on the control plot, while the number of plants was higher in the treated plots (105-139). The poppy plants had 1 leaf in every parcel on March 24, but the 9 leaf rosette form was reached already one week later and remained in this phase until the last decade of April. The shoot elongation was observed in the first half of May. The maximum internode number was between 6 and 9 per plant. The side shoots were observed from mid-May, numbering from 1 to 9 per plant. The first buds were developed in the first days of May, but only at the end of the month began the blooming period. The generative phase was wavy with flowering tops and breaks. The growth of fruits also began in the last days of May, and their final size was reached mid-June. The colourisation and ripening of fruits occurred at the end of June. Stocks were completely died until the first days of July.

No difference was found in the length data $(\mathrm{F}=1.585, \mathrm{SL}=0.185>\alpha)$. Only the width of the $25 \mathrm{~kg} / \mathrm{ha}$ treated plants was lower than on the $200 \mathrm{~kg} /$ ha treated plants $(\mathrm{F}=3.262, \mathrm{SL}=$ $0.015<\alpha)$. The analysis showed also significant difference in case of highness $(\mathrm{F}=11.856$, SL $<0.001)$. Based on pairwise comparison, the lowest individuals developed on the control plot. There were only differences between the smallest and the highest fertilizer application. Flowering period started 7 days earlier in the control plot, but there was no difference between the treated and control plots when examining the further development of the generative phase.

\section{CONCLUSION}

The treatments had no effect on the horizontal dimensions of the plants. At the same time, difference could be detected between the highness of control and treated plots, in the case of all three species. The difference is primarily due to the stimulating effect of potassium, which caused the elongation of flowering stems. It is interesting to note that the plants of Cyanus segetum and Consolida orientalis, were higher than the plants treated with nitrogen fertilizer treatment in the 2016 vegetation. This may also have the effect of different sowing times. The spring development (growth of rosette) began at $800^{\circ} \mathrm{C}$ in the case of 
Cyanus segetum and Papaver rhoeas, while the overwintered seedlings of Consolida orientalis developed after a heat sum of $900-1100^{\circ} \mathrm{C}$. The shoot elongation and the leaf number increase began at the same time in the case of cornflowers (after reaching $800^{\circ} \mathrm{C}$ ), while at least $1200^{\circ} \mathrm{C}$ heat sum was required for the flowering stem elongation of poppy. The vertical growth of larkspur started after reaching a heat sum of $900-1100^{\circ} \mathrm{C}$. The flower bud appearance and the shoot elongation began at the same time in the case of poppy, while in case of larkspur and cornflower there were 1-2 weeks between these two stages. The flowering period of three examined species began, when the heat sum reached $1450-1600^{\circ} \mathrm{C}$. The top of flowering was $1500-1650^{\circ} \mathrm{C}$ in case of Consolida orientalis; $1650-1800^{\circ} \mathrm{C}$ in case of Papaver rhoeas; and $1750-1850^{\circ} \mathrm{C}$ heat sum in the case of Cyanus segetum. Based on these data, it can be concluded that larkspur needs higher temperatures for vegetative development than the other two species. The rosettes of poppy needed more than a month to start of flowering stems elongation.

\section{ACKNOWLEDGEMENTS}

This research is supported by EFOP-3.6.1-16-2016-00006 "The development and enhancement of the research potential at John von Neumann University" project. The Project is supported by the Hungarian Government and co-financed by the European Social Fund.

\section{REFERENCES}

CAKMAK, I. (2005): The role of potassium in alleviating detrimental effects of abiotic stresses in plants. Journal of Plant Nutrition and Soil Science 168: 521-530.

HARgitAI, L. (2005): Talajtan és agrokémia II. (Alkalmazott talajtan és agrokémia). Budapest. pp. 186-196.

Hodossi, S. KovÁcs, A., Terbe, I. (2004): Zöldségtermesztés szabadföldön. Mezőgazda Kiadó, Budapest.

HoRINKA, T. (2010): Kertészeti növények komplett tápanyagellátása. Kertészek kis/Nagy Áruháza kft., Mórahalom.

LOCH, J., TERBE, I., VÁGÓ, I. (2006): Káliumtrágyázás szántóföldi és kertészeti kultúrákban. Nemzetközi Kálium Intézet, Horgen, Svájc.

PETHÖ, M. (2002): Mezőgazdasági növények élettana. Akadémiai Kiadó, Budapest.

SANGAKKARA, U. R., FreHNER, M., NÖSBERGER, J. (2000): Effect of soil moisture and potassium fertilizer on shoot water potential, photosynthesisand partitioning of carbon in mungbean and cowpea. Journal of Agronomy and Crop Science 185: 201-207. 